\section{Effect of Sprayer Output Volume and Adjuvants on Efficacy of Clove Oil for Weed Control in Organic Vidalia ${ }^{\circledR}$ Sweet Onion}

\author{
W. Carroll Johnson, $\mathrm{III}^{1,3}$ and Jerry W. Davis ${ }^{2}$
}

AdDitional index words. Allium cepa, dry-bulb onion, organic weed control

SUMMARY. Timely cultivation with a tine weeder and hand weeding are the primary tools for successful weed control in organic sweet onion (Allium cepa), but conditions frequently arise that delay the initial cultivation. Weeds that emerge during the delay are not effectively controlled by cultivation and herbicides derived from natural products may have a role to control the emerged weeds. It has been reported that clove oil herbicide was more effective when sprayers were calibrated for higher output (>50 gal/acre) compared with sprayers calibrated at $\approx \mathbf{2 5} \mathrm{gal} /$ acre. However, when clove oil was applied at the recommended rate of $10 \%$ by volume, herbicide cost was doubled when sprayer output volume was doubled. It was theorized that herbicide adjuvants might improve clove oil efficacy and reduce weed control cost by not needing to increase sprayer output volume. Trials were conducted from 2010 to 2012 to evaluate all possible combinations of two sprayer output volumes and five herbicide adjuvants used with clove oil ( $10 \%$ by volume) for cool season weed control. Sprayer output volumes evaluated were 25 and $50 \mathrm{gal} /$ acre, using spray tips of differing orifice size. Adjuvants evaluated were a material composed of saponins, citric acid plus garlic extract, an emulsified petroleum oil (EPO) insecticide, a conventional petroleum oil adjuvant (POA), no adjuvant used with clove oil, and a nontreated control. Weed control was not consistently improved by applying clove oil ( $10 \%$ by volume) with a sprayer calibrated at $50 \mathrm{gal} /$ acre compared with sprayer calibrated at $25 \mathrm{gal} / \mathrm{acre}$. Improvements in weed control that were occasionally seen did not affect onion yield. Adjuvants provided minimal improvement in weed control from clove oil and did not consistently improve onion yield. Based on these results, clove oil does not provide suitable levels of weed control in organic Vidalia ${ }^{\circledR}$ sweet onion production to justify the expense.

$\mathrm{O}$ rganic production systems rely heavily on cultural and mechanical weed control, with minimal dependence on herbicides that are approved for use in certified organic crops. Herbicides allowed for use in certified organic production systems are derived from natural sources. Some are derived from essential oils originating from plants (Dayan et al., 2009; Gaskell et al., 2000; Tworkoski, 2002). These herbicides are sprayable, applied postemergence, nonsystemic, and tend to be nonselective, although tolerance varies among crops.

We acknowledge the technical contributions of Daniel R. Evarts whose skills made these studies possible. Appreciation is expressed to C. Randy Hill and Denny $\mathrm{R}$. Thigpen at the Vidalia Onion and Vegetable Research Center for their support of this research study. We appreciate the managerial support and assistance rendered by Stephen Powell, Corrections Officer - II, Rodgers State Prison, Reidsville, GA.

${ }^{1}$ Research Agronomist, USDA-ARS, Tifton Campus, P.O. Box 748, Tifton, GA 31793-0748

${ }^{2}$ Research Statistician, University of Georgia, Griffin Campus, Griffin, GA 30223

${ }^{3}$ Corresponding author. E-mail: Carroll.Johnson@ ars.usda.gov.
Herbicides derived from essential oils have been investigated for weed control benefits in certified organic crop production. The majority of the reported studies on herbicides derived from natural products were on warm season crops and weeds. Other researchers have evaluated rates of several commercial products, application timing, and combinations with cultivation in many cropping systems and regions (Boyd and Brennan, 2006; Boyd et al., 2006; Curran et al., 2004; Johnson et al., 2012). Common conclusions drawn from these studies were that none of the essential oil herbicides provided any residual weed control, small weed size was critical for maximum efficacy, environmental conditions affected herbicide performance, and rates necessary for maximum efficacy made the treatment costly. Additionally, sprayer configuration was reported to be an important consideration to ensure maximum efficacy, with high sprayer output volume necessary to ensure adequate spray coverage of targeted weeds (Boyd and Brennan, 2006; Boyd et al., 2006; Curran et al., 2004; Evans and Bellinder, 2009; Shrestha et al., 2012; Young, 2004). Previous research showed that essential oil herbicides were ineffective when applied with sprayers calibrated for low output; 6 gal/acre (Brainard et al., 2013) and 8 gal/acre (Ferguson, 2004).

Vidalia ${ }^{\circledR}$ sweet onion is a drybulb onion grown in Georgia as a cool season crop. In 2011 , Vidalia ${ }^{\circledR}$ sweet onion production accounted for the largest portion $(20 \%)$ of the Georgia vegetable crop farm gate value compared with other vegetable crops (Wolfe and Shepherd, 2012). Vidalia ${ }^{\circledR}$ sweet onion plantings are restricted by Federal Marketing Order 955 to region in southeastern Georgia (U.S. Code of Federal Regulations, 1990). The acreage is stable, with the 2011 Vidalia sweet onion acreage estimated at 14,210 acres. Within this region, the economic impact of Vidalia ${ }^{\circledR}$ sweet onion production is substantial and valued at \$159 million.

There have been efforts in recent years to expand the niche market of certified organic Vidalia ${ }^{\circledR}$ sweet onion. Crop production budgets exist for organic Vidalia ${ }^{\circledR}$ sweet onion production (R.L. Torrance, unpublished data). The two most costly inputs into organic Vidalia ${ }^{\circledR}$ sweet onion production are cost of transplants ( $\$ 1800 /$ acre) and hand weeding ( $\$ 1500 /$ acre $)$. Any effective weed control system that reduces or eliminates the need for hand weeding will provide a significant

\begin{tabular}{lllc}
\hline $\begin{array}{l}\text { Units } \\
\begin{array}{l}\text { To convert U.S. to SI, } \\
\text { multiply by }\end{array}\end{array}$ & U.S. unit & SI unit & $\begin{array}{l}\text { To convert SI to U.S., } \\
\text { multiply by }\end{array}$ \\
\hline 0.4047 & acre(s) & $\mathrm{ha}$ & 2.4711 \\
0.3048 & $\mathrm{ft}$ & $\mathrm{m}$ & 3.2808 \\
0.0929 & $\mathrm{ft}^{2}$ & $\mathrm{~m}^{2}$ & 10.7639 \\
9.3540 & gal/acre & ${\mathrm{L} \cdot \mathrm{ha}^{-1}}^{-1}$ & 0.1069 \\
2.54 & inch(es) & $\mathrm{cm}$ & 0.3937 \\
25.4 & inch(es) & $\mathrm{mm}$ & 0.0394 \\
1.1209 & lb/acre & $\mathrm{kg} \cdot \mathrm{ha}^{-1}$ & 0.8922 \\
2.2417 & ton(s)/acre & $\mathrm{Mg} \cdot \mathrm{ha}^{-1}$ & 0.4461
\end{tabular}


savings directly to growers. Recent research efforts focused on an integrated system of summer solarization, cultivation with a tine weeder, and clove oil (Johnson et al., 2012), with the stated objective to lessen the need for hand weeding. Of the weed control tactics studied, cultivation with a tine weeder was the most consistent and effective approach. However, it was noted that timing of the initial cultivation was crucial and delays in the initial cultivation would greatly reduce overall weed control success. That research also indicated that clove oil provided inconsistent weed control benefits and its use was not correlated with yield responses. However, clove oil might provide a specialized niche in organic Vidalia ${ }^{\circledR}$ sweet onion production by controlling emerged seedling weeds, if consistency is improved. While the production region for Vidalia ${ }^{\circledR}$ sweet onion is in southeastern Georgia where winters are mild with rare incidence of snowfall or frozen soil, applications will be under winter conditions for the region. These conditions could reduce efficacy of contact herbicides like clove oil. Therefore, studies were initiated in 2010 to determine if herbicide adjuvants improve clove oil efficacy without the need for higher sprayer output volume in organic Vidalia ${ }^{\circledR}$ sweet onion production.

\section{Materials and methods}

Irrigated field trials were conducted from 2010 to 2012 at the Vidalia Onion and Vegetable Research Center near Lyons, GA (lat. $32.018801^{\circ} \mathrm{N}$, long. $82.220101^{\circ} \mathrm{W}$ ). This location is in the designated region where Vidalia ${ }^{\circledR}$ sweet onion is commercially produced. The soil was a Tifton loamy sand (fine-loamy, kaolinitic, thermic Plinthic Kandiudults), composed of $88 \%$ sand, $6 \%$ silt, and $6 \%$ clay, with $0.5 \%$ organic matter. The experimental design was a randomized complete block, with a factorial arrangement of treatments replicated four times. One treatment factor was sprayer output volume; sprayer calibrated at 25 and $50 \mathrm{gal} /$ acre. Herbicide treatments were applied with a carbon dioxide $\left(\mathrm{CO}_{2}\right)$-pressurized tractor-mounted plot sprayer using spray tips of differing orifice size to achieve the desired sprayer output volume (Turbo TeeJet ${ }^{\circledR} 11003$ and 11006 tips; TeeJet Technologies, Wheaton, IL).
The other treatment factor was adjuvants used with clove oil. An OMRI-listed clove oil herbicide (Matratec $^{\circledR}$ containing 50\% clove oil; Brandt Consolidated, Springfield, IL) was evaluated and applied at $10 \%$ by volume spray solution. The adjuvants for clove oil evaluated were a POA (Chem Nut Agri-Oil ${ }^{\circledR}$; Chem Nut, Albany, GA) at $1.25 \%$ by volume, a commercial product containing $20 \%$ citric acid [CAA (Biolink ${ }^{\circledR}$ Buffer and Penetrant; Westbridge, Vista, CA)] at a rate of $0.375 \%$ by volume, a commercial adjuvant containing $20 \%$ saponins (SA) extracted from $\Upsilon$ ucca schidigera (Therm $X 70^{\circledR}$; American Extracts, Strathmore, CA) at $0.03 \%$ by volume, an $\mathrm{EPO}$ insecticide (Saf-T-Side ${ }^{\circledR}$; Brandt Consolidated, Springfield, IL) at a rate of $1 \%$ by volume, clove oil alone (no adjuvant), and a nontreated control. The POA is a commonly used crop oil concentrate adjuvant in conventional production systems. The other adjuvants are approved for use in certified organic production systems. Herbicide treatments were applied in early January each year to weeds ranging in size from cotyledon to one-true leaf stage of growth. At the time of application, onion seedlings had recovered from transplanting and were $\approx 15 \mathrm{~cm}$ tall with a bulb diameter of $10 \mathrm{~mm}$.

Approved cultivars for Vidalia ${ }^{\circledR}$ sweet onion production [Savannah Sweet (2010 and 2011) and Sweet Vidalia (2012)] were grown according to National Organic Standards, although the experimental site was not certified organic due to proximity to conventionally grown crops. Transplants were produced in seedbeds that were direct seeded in September each year. Field sites were fertilized with 6 tons/acre of composted poultry litter [average analysis of $3.2 \%$ nitrogen $(\mathrm{N}), 2.2 \%$ phosphorous $(\mathrm{P}), 2.6 \%$ potassium $(\mathrm{K})]$ in November each year and soil incorporated with power tiller. This rate of composted poultry litter was based on previous studies that determined the recommended rates for organic Vidalia ${ }^{\circledR}$ sweet onion (Boyhan et al., 2010). In early December, seedbeds were again freshly tilled with a power tiller that also simultaneously marked transplant holes. Immediately after the final seedbed preparation, onions were transplanted by hand. Plots were $6 \mathrm{ft}$ wide by $20 \mathrm{ft}$ long, with four rows centered on the seedbed and each row 12 inches apart. Within each row, onion transplants were spaced 4 inches apart to achieve the optimum combination of yield and desirable grade (Boyhan and Kelley, 2008; Boyhan et al., 2009). To comply with national organic crop production standards, no additional fertilizer or maintenance pesticides were applied during these trials.

Weed counts were determined mid-March of each year. Weeds were counted in two $0.5-\mathrm{m}^{2}$ quadrats $(0.5 \times$ $1.0 \mathrm{~m}$ ) in each plot, centered over an onion row. Visual estimates of onion injury compared with nontreated controls were also assessed in mid-March. Onion yields from the entire plot were measured by mechanically undercutting and lifting onion at physiological maturity in early May each year. After field-curing for 1 week, roots and tops were clipped by hand and onion bulbs graded by size according to established standards (U.S. Department of Agriculture, 1995). Diseased, misshapen, and small onion bulbs were discarded during the grading process. Onion yields were recorded by grade and total yield.

Data were analyzed using a mixedmodel analysis. Degrees of freedom were partitioned to test singularly and in combination the effects of sprayer output volume and clove oil herbicide adjuvants on weed control and onion yield parameters. Means were separated using Fisher's protected least significant difference test at $P \leq 0.05$.

\section{Results and discussion}

Data were analyzed by year due to differences in growing conditions among years and baseline weed infestations that differed among sites. Onion yields were not measured in 2012 due to extreme transplant mortality caused by herbicide carryover from applications to previous crops in the transplant production site. There was no interaction between the main effects of sprayer output volume and clove oil adjuvants for any of the parameters evaluated each year of the study. Therefore, all data are presented as main effects.

WeEd CONTROL. Cutleaf eveningprimrose (Oenothera laciniata) was the predominant weed each year, with densities ranging from 24 to 71 plants $/ \mathrm{m}^{2}$ in the nontreated controls. Densities of cutleaf evening-primrose were unaffected by sprayer output 
Table 1. Main effects of sprayer output volume and adjuvants with clove oil on weed densities in organic Vidalia ${ }^{\circledR}$ sweet onion at Lyons, GA in 2010-12.

\begin{tabular}{|c|c|c|c|c|c|c|c|c|c|c|}
\hline \multirow[b]{3}{*}{ Main effect } & \multicolumn{10}{|c|}{ Midseason weed density $\left(\text { no. } / \mathrm{m}^{2}\right)^{\mathrm{z}}$} \\
\hline & \multicolumn{3}{|c|}{ Cutleaf evening-primrose } & \multicolumn{2}{|c|}{ Henbit } & \multirow{2}{*}{$\frac{\text { Swinecress }}{2011}$} & \multirow{2}{*}{$\frac{\text { Common chickweed }}{2012}$} & \multicolumn{3}{|c|}{ Total weed density } \\
\hline & 2010 & 2011 & 2012 & 2010 & 2011 & & & 2010 & 2011 & 2012 \\
\hline $25 \mathrm{gal} / \mathrm{acre}^{\mathrm{z}}$ & $66.8 \mathrm{a}^{\mathrm{x}}$ & $18.1 \mathrm{a}$ & $14.3 \mathrm{a}$ & $16.9 \mathrm{a}$ & $9.5 \mathrm{a}$ & $8.6 \mathrm{a}$ & $4.9 \mathrm{a}$ & $83.7 \mathrm{a}$ & $36.2 \mathrm{a}$ & $20.3 \mathrm{a}$ \\
\hline $50 \mathrm{gal} / \mathrm{acre}$ & $88.6 \mathrm{a}$ & $17.1 \mathrm{a}$ & $14.8 \mathrm{a}$ & $11.0 \mathrm{~b}$ & $5.0 \mathrm{~b}$ & $7.8 \mathrm{a}$ & $4.1 \mathrm{a}$ & 99.6 a & $29.8 \mathrm{a}$ & $19.7 \mathrm{a}$ \\
\hline \multicolumn{11}{|l|}{ Clove oil treatment ${ }^{\mathrm{w}}$} \\
\hline Clove oil + SA & $82.0 \mathrm{a}$ & $11.6 \mathrm{~b}$ & $12.6 \mathrm{~b}$ & $14.3 \mathrm{a}$ & $5.1 \mathrm{~b}$ & $5.3 \mathrm{ab}$ & $5.0 \mathrm{ab}$ & $96.3 \mathrm{a}$ & $22.0 \mathrm{bc}$ & $18.4 \mathrm{~b}$ \\
\hline Clove oil + EPO & $71.3 \mathrm{a}$ & $12.6 \mathrm{~b}$ & $13.9 \mathrm{~b}$ & $13.8 \mathrm{a}$ & $2.9 \mathrm{~b}$ & $3.3 \mathrm{~b}$ & $3.1 \mathrm{~b}$ & $85.0 \mathrm{a}$ & $18.8 \mathrm{bc}$ & $17.9 \mathrm{~b}$ \\
\hline Clove oil & $84.3 \mathrm{a}$ & $7.9 \mathrm{~b}$ & $11.0 \mathrm{~b}$ & $11.8 \mathrm{a}$ & $8.9 \mathrm{ab}$ & $9.6 \mathrm{ab}$ & $6.6 \mathrm{a}$ & $96.0 \mathrm{a}$ & $26.4 \mathrm{bc}$ & $18.3 \mathrm{~b}$ \\
\hline Nontreated control & $70.8 \mathrm{a}$ & $49.3 \mathrm{a}$ & $23.9 \mathrm{a}$ & $17.3 \mathrm{a}$ & $15.3 \mathrm{a}$ & $18.8 \mathrm{a}$ & $5.1 \mathrm{ab}$ & $88.0 \mathrm{a}$ & $83.3 \mathrm{a}$ & $31.0 \mathrm{a}$ \\
\hline
\end{tabular}

${ }^{2} 1$ weed $/ \mathrm{m}^{2}=0.0929$ weed $/ \mathrm{ft}^{2}, \mathrm{l} \mathrm{gal} /$ acre $=9.3540 \mathrm{~L} \cdot \mathrm{ha}^{-1}$.

y Sprayer output volume data are main effects, combined across clove oil treatment regimes.

${ }^{x}$ Within each main effect, means in a column followed by the same letter are not different according to Fisher's protected least significant difference test at $P \leq 0.05$

${ }^{w}$ Clove oil treatment regime data are main effects, combined across sprayer output volumes; CAA = adjuvant with $20 \%$ citric acid, EPO = emulsified petroleum oil insecticide used as an adjuvant, POA = petroleum oil adjuvant, $\mathrm{SA}=$ adjuvant with $20 \%$ saponins.

Table 2. Main effects of sprayer output volume and adjuvants crop injury and yield in organic Vidalia ${ }^{\circledR}$ sweet onion at Lyons, GA in 2010 and 2011 .

\begin{tabular}{|c|c|c|c|c|c|c|c|c|}
\hline \multirow[b]{3}{*}{ Main effect } & \multicolumn{8}{|c|}{ Onion yield $\left(\mathrm{kg} \cdot \mathrm{ha}^{-1}\right)^{\mathrm{z}}$} \\
\hline & \multicolumn{2}{|c|}{ Visual injury (\%) } & \multicolumn{2}{|c|}{ Medium } & \multicolumn{2}{|c|}{ Jumbo } & \multicolumn{2}{|c|}{ Total yield } \\
\hline & 2010 & 2011 & 2010 & 2011 & 2010 & 2011 & 2010 & 2011 \\
\hline $25 \mathrm{gal} / \mathrm{acre}^{\mathrm{z}}$ & $6 b^{x}$ & $15 \mathrm{~b}$ & $9,390 \mathrm{a}$ & $13,600 \mathrm{a}$ & $660 \mathrm{a}$ & $15,490 \mathrm{~b}$ & $10,060 \mathrm{a}$ & $29,180 \mathrm{~b}$ \\
\hline $50 \mathrm{gal} /$ acre & $13 \mathrm{a}$ & $24 \mathrm{a}$ & $9,650 \mathrm{a}$ & $13,400 \mathrm{a}$ & $1,010 \mathrm{a}$ & $20,450 \mathrm{a}$ & $10,660 \mathrm{a}$ & $34,080 \mathrm{a}$ \\
\hline \multicolumn{9}{|l|}{ Clove oil treatment ${ }^{\mathrm{w}}$} \\
\hline Clove oil + SA & $9 \mathrm{~b}$ & $24 \mathrm{a}$ & $9,750 \mathrm{ab}$ & $13,520 \mathrm{a}$ & $750 \mathrm{ab}$ & $21,710 \mathrm{a}$ & $10,500 \mathrm{ab}$ & $35,560 \mathrm{a}$ \\
\hline Clove oil + EPO & $9 \mathrm{~b}$ & $25 \mathrm{a}$ & $10,410 \mathrm{a}$ & $13,500 \mathrm{a}$ & $960 \mathrm{ab}$ & $22,340 \mathrm{a}$ & $11,360 \mathrm{a}$ & $36,060 \mathrm{a}$ \\
\hline Clove oil & $18 \mathrm{a}$ & $25 \mathrm{a}$ & $8,830 \mathrm{ab}$ & $12,120 \mathrm{a}$ & $450 \mathrm{~b}$ & $18,040 \mathrm{a}$ & $9,270 \mathrm{ab}$ & $30,280 \mathrm{a}$ \\
\hline Nontreated control & $0 \mathrm{c}$ & $0 \mathrm{~b}$ & $7,970 \mathrm{~b}$ & $13,770 \mathrm{a}$ & $300 \mathrm{~b}$ & $7,390 \mathrm{~b}$ & $8,270 \mathrm{~b}$ & $21,220 \mathrm{~b}$ \\
\hline
\end{tabular}

${ }^{\mathrm{z}} \mathrm{l} \mathrm{kg} \cdot \mathrm{ha}^{-1}=0.8922 \mathrm{lb} /$ acre, $1 \mathrm{gal} /$ acre $=9.3540 \mathrm{~L} \cdot \mathrm{ha}^{-1}$

'Sprayer output volume data are main effects, combined across clove oil treatment regimes.

'Within each main effect, means in a column followed by the same letter are not different according to Fisher's protected least significant difference test at $P \leq 0.05$.

${ }^{\text {w}}$ Clove oil treatment regime data are main effects, combined across sprayer output volumes; CAA = adjuvant with $20 \%$ citric acid, EPO = emulsified petroleum oil insecticide used as an adjuvant, $\mathrm{POA}=$ petroleum oil adjuvant, $\mathrm{SA}=$ adjuvant with $20 \%$ saponins.

volume each year of the study (Table 1). In 2010, none of the adjuvants used with clove oil affected cutleaf evening-primrose density compared with the nontreated control. All clove oil treatments reduced cutleaf evening-primrose density compared with the nontreated control in 2011 (71\% to $84 \%$ reduction) and 2012 ( $39 \%$ to $54 \%$ reduction), although using adjuvants with clove oil did not reduce cutleaf evening-primrose density compared with clove oil alone.

Henbit (Lamium amplexicaule) was present in 2010 and 2011 , with densities ranging from 15 to 17 plants/ $\mathrm{m}^{2}$ in the nontreated control (Table $\mathrm{l}$ ). In both years, henbit density was lower when herbicide treatments were applied with sprayer output volume at $50 \mathrm{gal} /$ acre compared with 25 gal/acre. Clove oil, with or without adjuvants, did not affect henbit density compared with the nontreated control in 2010. In 2011, adjuvants applied with clove oil did not reduce henbit density over clove oil alone, although henbit density was reduced by using clove oil with all adjuvants (58\% to $81 \%$ reduction) compared with the nontreated control.

Swinecress (Coronopus didymus) was present only in 2011, with densities averaging 19 plants $/ \mathrm{m}^{2}$ in the nontreated control. Sprayer output volume had no effect on swinecress density (Table 1). Adjuvants used with clove oil did not affect swinecress density compared with clove oil alone, and there were no differences in swinecress density among any of the clove oil adjuvants. However, clove oil plus either EPO or POA reduced swinecress densities (82\% and $84 \%$, respectively) compared with the nontreated control. Common chickweed (Stellaria media) was present in 2012, with densities averaging 5 plants $/ \mathrm{m}^{2}$ in the nontreated control. Sprayer output volume had no effect on common chickweed density (Table 1). Common chickweed density did not differ among the adjuvants used with clove oil. The POA and EPO adjuvants used with clove oil reduced common chickweed 
density compared with clove oil alone, but these densities did not differ from the nontreated control.

Densities of all weeds were combined, with total weed density ranging from 31 to 88 plants $/ \mathrm{m}^{2}$ in the nontreated control (Table 1 ). Total weed density did not differ between sprayer output volumes of 25 and $50 \mathrm{gal} /$ acre each year of the study. None of the clove oil treatments affected the total weed density in 2010 and there was no difference in total weed density among the adjuvants used with clove oil compared with clove oil alone. In 2011 and 2012, all clove oil treatments reduced total weed density over the nontreated control, but none of the adjuvants used with clove oil reduced total weed density compared with clove oil alone.

ONION VISUAL INJURY. In 2010 and 2011, clove oil applied with a sprayer output volume of $50 \mathrm{gal} /$ acre were more injurious (13\% to $24 \%$ ) than clove oil applied in a sprayer output volume of $25 \mathrm{gal} / \mathrm{acre}$ ( $6 \%$ to $15 \%$ ) (Table 2). This is logical since the total amount of clove oil applied in a sprayer calibrated at $50 \mathrm{gal} / \mathrm{acre}$ is twice the volume of clove oil applied in a sprayer calibrated at $25 \mathrm{gal} /$ acre. Compared with the nontreated control, all clove oil treatments significantly injured onion both years. In 2010 , clove oil alone was the most injurious treatment, with adjuvants reducing visual injury from clove oil. However, there was no difference in visual injury to onion among clove oil herbicide treatments in 2011.

ONION YIELD. Yield of mediumsized onions were unaffected by sprayer output volume when applying clove oil herbicide in 2010 and 2011 (Table 2). Jumbo-sized onion yields were unaffected by sprayer output volume in 2010 , but were greater in 2011 when treatments were applied with a sprayer calibrated at $50 \mathrm{gal} / \mathrm{acre}$ compared with sprayer calibrated at $25 \mathrm{gal} /$ acre. Similarly, total onion yield across all sizes were unaffected by sprayer output volume in 2010 , but were greater in 2011 when clove oil herbicides were applied with a sprayer calibrated at $50 \mathrm{gal} /$ acre compared with $25 \mathrm{gal} / \mathrm{acre}$. This was presumably due to improved weed control when clove oil herbicides were applied with a sprayer calibrated at $50 \mathrm{gal} /$ acre, since visual injury was actually greater with the higher sprayer output volume (Table 2). However, weed densities were largely unaffected by sprayer output volume, other than henbit in 2010 and 2011 (Table 1). Therefore, the reason for greater yield of jumbo-sized onion in 2011 and total onion yield in 2010 and 2011 cannot be definitively explained.

Onion yield response to applications of clove oil and adjuvants was not consistent. There was no difference in medium-sized onion yield among plots treated with clove oil in 2010 and 2011 , with no difference between any of the clove oil treatments and the nontreated control in 2011 (Table 2). Yield of jumbo-sized onion did not differ among the adjuvants used with clove oil in 2010. In 2011, all clove oil treatments increased jumbo-sized onion yield compared with the nontreated control, but adjuvants tested with clove oil did not increase jumbo-sized onion yield over clove oil alone. There was no difference in total onion yield among plots treated with clove oil, regardless of the use of an adjuvant. Onion treated with clove oil using a POA, CAA, or EPO adjuvant had greater total yield than the nontreated control in 2010. In 2011, all clove oil treatments, including clove oil alone, increased total onion yield compared with the nontreated control.

Evans and Bellinder (2009) tested clove oil for weed control in directseeded onion grown as a warm season crop in New York. In their trials, warm season weeds were controlled and onion biomass was improved by applying clove oil for weed control. In previous studies using clove oil for cool season weed control in Vidalia ${ }^{\circledR}$ sweet onion, weed control was inconsistent and yields were unaffected (Johnson et al., 2012). The results in these studies were generally the same; control of cool season weeds during winter months with clove oil were inconsistent. Increasing sprayer output volume from 25 to $50 \mathrm{gal} / \mathrm{acre}$ did not consistently improve weed control or increase onion yield. Adjuvants did not consistently improve clove oil efficacy and onion yields were not improved. The lack of interaction between sprayer output volume and adjuvants used with clove oil indicated that adjuvants do not compensate for slightly improved cool season weed control from clove oil applied with a sprayer calibrated at 50 gal/acre compared with a sprayer calibrated at $25 \mathrm{gal} /$ acre.

Given the lack of weed response and onion yields to clove oil applied in higher sprayer output volumes and the corresponding increase in clove oil cost when increasing sprayer output volume, we cannot recommend clove oil in organic Vidalia ${ }^{\circledR}$ sweet onion production systems. Cool season weeds such as cutleaf eveningprimrose, henbit, and swinecress do not appear to be overly susceptible to the herbicide. Furthermore, there was extreme difficulty in timing herbicide applications in these trials when weeds were small and weather conditions were optimized for herbicide performance during winter months. Additionally, it was noted that all clove oil herbicide treatments, regardless of adjuvant, had difficulty in maintaining an emulsion in the spray tank and needed near-constant agitation. This tendency proved to be very problematic and suggests another disadvantage to using clove oil for weed control in certified organic crop production.

\section{Literature cited}

Boyhan, G.E. and W.T. Kelley. 2008. Onion production guide. Univ. Georgia Ext. Serv. Bul. 198-2.

Boyhan, G.E., R.J. Hicks, R.L. Torrance, C.M. Riner, and C.R. Hill. 2010. Evaluation of poultry litter and organic fertilizer rate and source for production of organic short-day onion. HortTechnology 20:304 307.

Boyhan, G.E., R.L. Torrance, J. Cook, C. Riner, and C.R. Hill. 2009. Plant population, transplant size, and variety effect on transplanted short-day onion production. HortTechnology 19:145-151.

Boyd, N.S. and E.B. Brennan. 2006. Burning nettle, common purslane, and rye response to a clove oil herbicide. Weed Technol. 20:646-650.

Boyd, N.S., E.B. Brennan, and S.A. Fennimore. 2006. Stale seedbed techniques for organic vegetable production. Weed Technol. 20:1052-1057.

Brainard, D.C., W.S. Curran, R.R. Bellinder, M. Ngouajio, M.J. VanGessel, M.J. Haar, W.T. Lanini, and J.B. Masiunas. 2013. Temperature and relative humidity affect weed response to vinegar and clove oil. Weed Technol. 27:156-164.

Curran, W.S., D.D. Lingenfelter, and C.B. Muse. 2004. Vinegar and clove oil 


\section{Research Reports}

for non-selective control of annual weeds. Proc. Northeastern Weed Sci. Soc. 58:21. (abstr.).

Dayan, F.E., C.L. Cantrell, and S.O. Duke. 2009. Natural products in crop production. Bioorg. Med. Chem. 17: 4022-4034.

Evans, G.J. and R.R. Bellinder. 2009. The potential use of vinegar and a clove oil herbicide for weed control in sweet corn, potato, and onion. Weed Technol. 23: $120-128$

Ferguson, J. 2004. Evaluation of organic herbicides. HortScience 39:876. (abstr.).

Gaskell, M., B. Fouche, S. Koike, T. Lanini, J. Mitchell, and R. Smith. 2000. Organic vegetable production in California Science and practice. HortTechnology 10:699-713.
Johnson, W.C., III, D.B. Langston, Jr. D.D. MacLean, F.H. Sanders, Jr., R.L. Torrance, and J.W. Davis. 2012. Integrated systems of weed management in organic transplanted Vidalia ${ }^{\circledR}$ sweet onion production. HortTechnology 22:64-69.

Shrestha, A., M. Moretti, and N. Mourad. 2012. Evaluation of thermal implements and organic herbicides for weed control in a nonbearing almond (Prunus dulcis) orchard. Weed Technol. 26:110-116.

Tworkoski, T. 2002. Herbicide effects of essential oils. Weed Sci. 50:425-431.

U.S. Code of Federal Regulations. 1990. Title 7: Agriculture. Part 955-Vidalia onions grown in Georgia. 15 May 2014. <http://www.ecfr.
gov/cgi-bin/retrieveECFR? gp $=\& S I D=$ a9a494leef9dca3d7131f7fdd5e5a995\&r= PART\&n=7y8.1.1.1.21 $>$.

U.S. Department of Agriculture. 1995. United States standards for grades of bermuda-granex-grano type onions. U.S. Dept. Agr., Washington, DC.

Wolfe, K. and T. Shepherd. 2012. 2011 Georgia farm gate value report. Univ. Georgia Ctr. Agribusiness Econ. AR-12-01. 15 May 2014. <http://www.caes.uga.edu/ center/caed/documents/FinalGeorgiaFarmGateReport01-14-2013.pdf>.

Young, S.L. 2004. Natural product herbicides for control of annual vegetation along roadsides. Weed Technol. 18:580587. 